\title{
The impact of different organic fertilizers of urban origin on the caliber and yield of two vegetable crops
}

\author{
Naïma Tahraoui Douma*1, Walid Meftah ${ }^{* 2}$, Bakhta Zorkane ${ }^{* 2}$, Serge Chambon ${ }^{* 3}$ \\ ${ }^{1}$ Laboratories: Water and Environment, university of Hassiba Benbouali of Chlef, \\ BP 151 Hay Essalam 02000 Chlef, Algeria, Center of Technology Resource for environmental (ODESSOL), \\ National School of Engineering of Limoges (ENSIL) and Group for Water, Soil and Environment, \\ 16 rue Atlantis Parc ESTER Technopole 87068 Limoges, France. \\ 1n.tahraoui@univ-chlef.dz \\ ${ }^{2}$ University of Hassiba Benbouali of Chlef, BP 151 Hay Essalam 02000 Chlef, Algeria. \\ ${ }^{2}$ Walid.meftah@hotmail.com \\ ${ }^{2}$ Zorkane mohamed@hotmail.com \\ ${ }^{3}$ Laboratories: Center of Technology Resource for environmental (ODESSOL), \\ National School of Engineering of Limoges (ENSIL) and Group for Water, Soil and Environment, \\ 16 rue Atlantis Parc ESTER Technopole 87068 Limoges, France. \\ ${ }^{3}$ serge.chambon@unilim.fr
}

\begin{abstract}
The application of the organic fertilizers in soils is essential to maintain soil fertility and increase crop productivity. Organic fertilizers improve the physical, chemical and biological characteristics of soils.

Different compost derived from the composting of the waste fermentable, are used in this experiment. The composts have different particle sizes $(10 \mathrm{~mm}$ and $40 \mathrm{~mm})$. The latter has basic pH values (8-9), C/N ratios varying between 17, 7 and 19, 7. The organic matter rate, answer to norm NFU 44051 (varying between $34 \%$ and $48 \%$ ). The analyses of the elements trace metallic show that the rates are in conformity with the international standards of organic amendments. The results of phytotoxicity show that the composts are mature.
\end{abstract}

The different compost (fine and coarse) added to mineral fertilizers gives of the rates high of potatoes (50 $\%, 50,8 \%$ ) and turnips $(59,5 \%, 62 \%)$, whose the caliber is over $55 \mathrm{~mm}$. This shows that compost is a necessary additive to minerals fertilizers since it acts as an organic amendment for the fertility of arable soils, and it acts as a mineral amendment for a better productivity of the different cultures.

Keywords: Urban fermentable wastes, co-composting, organic amendments, recycling for agricultural, soil fertilization.

\section{INTRODUCTION}

In Algeria, the department of Chlef has an agricultural vocation. More than 203000 hectares, is the Useful Agricultural Area (UAA) and 18000 hectare is the Agricultural Area Irrigated (AAI) (Directorate of agriculture of the department, 2015). Soils in the Chlef area are generally clayey. The textures of the agricultural soils are loamy and sandy with an intermediate environment, clay-loamy and silty-sandy. All these types of soils are very poor in organic matter. The rate of this latter varies between $0 \%$ and $2 \%$. Therefore, the application of organic amendments to these soils is a necessity. At Chlef currently, contributions of mineral fertilizers (NPK) are 40,913 quintals / year and the needs are 24,548 quintals / year. This lack is brought by the compost

The organic matter, while maintaining structural stability, makes the soil structure more permeable to water and air [11]. It serves as a support and nourishment for biological activity [11], and also retains wate

The aim of this work is to establish experimentally the agricultural use of the compost produced from the green waste and the fermentable waste urban solid. This experiment is devoted to the effects of the compost on the yield and on caliber of potatoes and turnips.

According to the Directorate of Agricultural Services (DAS) of Chlef (2016), the potato production occupied the second place after the culture of the cereals. More than 2,081 hectares in Boukadir, Ouled Fares, Chlef and Oued Fodda are reserved for this crop. The minimum production rate for this crop is 250 quintals/ha, with an average of 350 to 360 quintals/ha. The maximum is 400 quintals/ha. But this maximum is obtained with a dose and a half of mineral fertilizers. And the turnip occupies the fourth place after the cultivation of other vegetables. The harvest rate is 79 quintals/ha. 


\section{MATERIALS AND METHODS}

\section{A. Composition of various composts}

The composition of the composts is based on their initial substrates:

- composting of $25 \%$ of urban fermentable with $75 \%$ of the green waste gives compost $1\left(\mathrm{C}_{1}\right)$.

- composting of $50 \%$ urban fermentable with $50 \%$ of the green waste gives compost $2\left(\mathrm{C}_{2}\right)$.

- composting of $75 \%$ of urban fermentable with $25 \%$ of the green waste gives compost $1\left(\mathrm{C}_{3}\right)$.

- composting of $100 \%$ fermentable urban gives compost $4\left(\mathrm{C}_{4}\right)$.

The various composts were screened with $10 \mathrm{~mm}$ and $40 \mathrm{~mm}$ square mesh sieves (table I).

TABLE I. Symbol of the composts after sieving

\begin{tabular}{|c|c|c|}
\hline Sieving of the compost & $\leq \mathbf{1 0} \mathbf{m m}$ & $\leq \mathbf{4 0} \mathbf{m m}$ \\
\hline Compost $\mathrm{C}_{1}$ & $\mathrm{C}_{1 / 10}$ & $\mathrm{C}_{1 / 40}$ \\
\hline Compost $\mathrm{C}_{2}$ & $\mathrm{C}_{2 / 10}$ & $\mathrm{C}_{2 / 40}$ \\
\hline Compost $\mathrm{C}_{3}$ & $\mathrm{C}_{3 / 10}$ & $\mathrm{C}_{3 / 40}$ \\
\hline Compost $\mathrm{C}_{4}$ & $\mathrm{C}_{4 / 10}$ & $\mathrm{C}_{4 / 40}$ \\
\hline
\end{tabular}

\section{B. Compost quality parameters}

The measurements and analysis of the parameters must be reliable and decisive for the efficiency of the process and for the use of the compost produced as an organic amendment.

Fig. 1 represents a descriptive diagram of the experimental protocol for all measurements and analyzes of the physicochemical parameters of the product composts

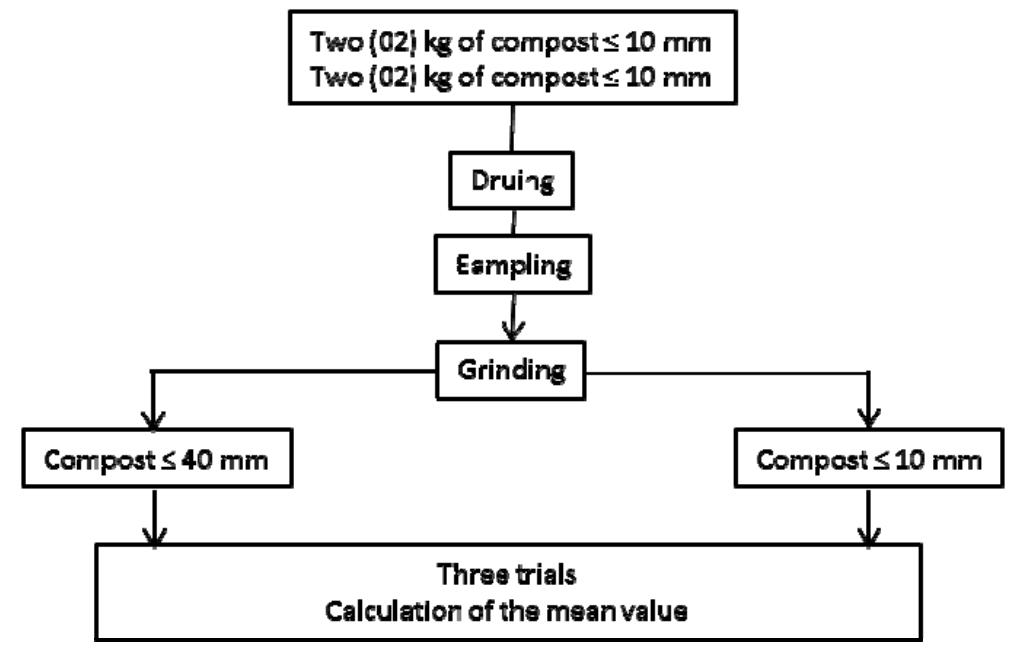

Fig. 1. Descriptive diagram of the experimental protocol

Table II lists the methods for analysis the quality and maturity parameters of the different composts produced.

TABLE II. Methods of analysis

\begin{tabular}{|c|c|c|c|c|c|}
\hline $\begin{array}{c}\text { Quality of } \\
\text { compost }\end{array}$ & $\begin{array}{c}\text { \% Organic } \\
\text { Matter/DM (Dry } \\
\text { Matter) }\end{array}$ & $\begin{array}{c}\text { \% } \\
\text { Carbon/DM }\end{array}$ & $\begin{array}{c}\text { Rate N } \\
\text { (NTK) }\end{array}$ & $\begin{array}{c}\text { Rate of the } \\
\text { Elements Metallic } \\
\text { Trace }\end{array}$ & $\begin{array}{c}\text { Rate of the } \\
\text { Fertilizer } \\
\text { Elements }\end{array}$ \\
\hline Methods & $\begin{array}{c}\text { Loss to fire } \\
\text { (Norm NFU } \\
44160)\end{array}$ & {$[9]$} & $\begin{array}{c}\text { Dosage of } \\
\text { Kjeldahl }\end{array}$ & $\begin{array}{c}\text { Method of analysis } \\
\text { ISO 11 460 of June } \\
1995 .\end{array}$ & $\begin{array}{c}\text { Method of } \\
\text { analysis ISO } \\
11460 \text { of } \\
\text { June } 1995 .\end{array}$ \\
\hline $\begin{array}{c}\text { Maturity } \\
\text { of compost }\end{array}$ & Germination test & $\begin{array}{c}\text { Germination } \\
\text { index test }\end{array}$ & - & - & - \\
\hline Methods & $\begin{array}{c}\text { World Health } \\
\text { Organization, 1978. }\end{array}$ & {$[13]$} & - & - & - \\
\hline
\end{tabular}




\section{1) Agronomic trials}

The agronomic trials were carried out on the agricultural plots of the station agronomical experimental of University of Chlef.

\section{2) Choice of soil}

-The soil selection criteria were: - Sol of the agronomic experimental station; - Uncontaminated soil that has not received no treatment (no organics amendments and no mineral fertilizers) since five (5) to six (6) years; Irrigation of agricultural crops ensured by the station employees; - Station closed to ensure crop safety with regard to animals; - Availability of the station employees for all work (seeding and harvesting).

\section{Methods of random blocks}

\section{1) Description}

The various treatments are nineteen (19) with a control (T). The control contains neither mineral fertilizer nor compost. The dose M of mineral fertilizers is 10 quintals per hectare NPK 15.15.15

Three (3) quintals per hectare of urea $46 \% \mathrm{~N}$ and $\mathrm{M}$ 'represents half of the latter. On the other hand, all doses of the different compost are at dose $\mathrm{D}$ (30 tons per hectare).

The doses of the various compost and the doses of the minerals fertilizers in the three blocks $\left(\mathrm{B}_{\mathrm{i}}, \mathrm{B}_{\mathrm{ii}}\right.$ and $\left.\mathrm{B}_{\mathrm{iii}}\right)$ are random and at the same time it is a repetition of these treatments. That is, the three trials are identical in the three blocks except that the doses in the mini plots are random (table III).

The area of each mini-plot is six square meters $\left(6 \mathrm{~m}^{2}\right)$ for growing potatoes. For the cultivation of turnips, each mini-plot has an area of four square meters $\left(4 \mathrm{~m}^{2}\right)$. In each block, the mini plots are separated by one meter $(1$ $\mathrm{m})$. The three blocks are separated by two meters $(2 \mathrm{~m})$ from each other.

TABLE III. Distribution of treatments by mini-plots in the three blocks

\begin{tabular}{|c|c|c|c|c|c|c|c|c|c|c|c|c|}
\hline Blocks & \multicolumn{4}{|c|}{ Block i } & \multicolumn{4}{|c|}{ Block ii } & \multicolumn{4}{|c|}{ Block iii } \\
\hline \multirow{5}{*}{$\begin{array}{l}\text { Seeding } \\
\text { of } \\
\text { potatoes }\end{array}$} & $\mathbf{T} 2 \mathbf{m}$ & $\mathbf{M}$ & $C_{1 / 10}$ & $C_{1 / 40}$ & M & $T$ & $\mathrm{C}_{2 / 10}$ & $\mathrm{C}_{2 / 40}$ & $\begin{array}{l}C_{2 / 10} \\
+M / 2\end{array}$ & $\begin{array}{c}C_{2 / 10}+C_{2} \\
140\end{array}$ & $\begin{array}{c}C_{1 / 10}+C_{1 /} \\
40\end{array}$ & $\mathbf{T}$ \\
\hline & $C_{2 / 10}$ & $C_{2 / 40}$ & $C_{1 / 10}+C_{1 / 4 C}$ & $C_{2 / 10}+C_{2}$ & $C_{1 / 10}$ & $C_{1 / 40}$ & $\mathrm{C}_{1 / 10}+\mathrm{M}$ & $\begin{array}{l}C_{1 / 10} \\
+M / 2\end{array}$ & $C_{1 / 10+N}$ & $C_{1 / 40}$ & $C_{1 / 10}$ & $\begin{array}{l}C_{2 / 40} \\
+M\end{array}$ \\
\hline & $C_{1 / 10}+M$ & $C_{1 / 10}+M / 2$ & $C_{2 / 10}+M$ & $\begin{array}{l}C_{2 / 10} \\
+M / 2\end{array}$ & $C_{2 / 10}+M$ & $\mathrm{C}_{2 / 40}+\mathrm{M}$ & $\begin{array}{c}C_{1 / 10}+C_{1 /} \\
40\end{array}$ & $\begin{array}{c}\mathrm{C}_{2 / 10}+\mathrm{C}_{2 l} \\
40\end{array}$ & $\begin{array}{l}C_{1 / 10} \\
+M / 2\end{array}$ & $\begin{array}{l}C_{2 / 10} \\
+M / 2\end{array}$ & $\begin{array}{c}C_{2 / 10}+C_{2 l} \\
40+M\end{array}$ & $\begin{array}{l}C_{2 / 10} \\
+M / 2\end{array}$ \\
\hline & $\begin{array}{c}C_{1 / 10}+C_{1 / 40} \\
+M\end{array}$ & $\begin{array}{c}C_{1 / 10}+C_{1 / 40} \\
+M / 2\end{array}$ & $\begin{array}{c}\mathrm{C}_{2 / 10}+\mathrm{C}_{2 / 40} \\
+\mathrm{M}\end{array}$ & $\begin{array}{c}\mathrm{C}_{2 / 10}+\mathrm{C}_{2 !} \\
{ }_{0}+\mathrm{M} / 2\end{array}$ & $\begin{array}{l}C_{1 / 10} \\
+M / 2\end{array}$ & $\begin{array}{c}C_{1 / 10^{+}}+ \\
M / 2\end{array}$ & $\begin{array}{l}C_{2 / 10} \\
+M / 2\end{array}$ & $\begin{array}{l}C_{2 / 40} \\
+M / 2\end{array}$ & $\begin{array}{l}C_{1 / 10}+C_{1 /} \\
40+M / 2\end{array}$ & $\mathrm{C}_{1 / 10}+\mathrm{M}$ & $\begin{array}{c}C_{2 / 10}+C_{2 /} \\
40+M / 2\end{array}$ & $\begin{array}{c}C_{1 / 10^{+}} \\
C_{1 / 40} \\
+M\end{array}$ \\
\hline & $\mathrm{C}_{3 / 40}+\mathrm{M}$ & $C_{3 / 40}+M / 2$ & $\mathrm{C}_{4 / 40}+\mathrm{M}$ & $\begin{array}{l}C_{4 / 40} \\
+M / 2\end{array}$ & $\begin{array}{c}C_{1 / 10}+C_{1 /} \\
40+M / 2\end{array}$ & $\begin{array}{c}\mathrm{C}_{1 / 10}+\mathrm{C}_{1 /} \\
40+\mathrm{M}\end{array}$ & $\mathrm{C}_{1 / 10}+\mathrm{M}$ & $\mathrm{C}_{1 / 40}+\mathrm{M}$ & M & $C_{4 / 40}$ & $\begin{array}{l}C_{3 / 10} \\
+M / 2\end{array}$ & $C_{4 / 10}$ \\
\hline \multirow{5}{*}{$\begin{array}{l}\text { Seeding } \\
\text { of } \\
\text { turnips }\end{array}$} & $2 \mathrm{~m}$ & M' & $C_{3 / 10}$ & $\mathrm{C}_{3 / 40}$ & M' & $T$ & $C_{4 / 10}$ & $C_{4 / 40}$ & $\begin{array}{l}C_{4 / 10} \\
+M^{\prime} / 2\end{array}$ & $\begin{array}{c}\mathrm{C}_{4 / 10}+\mathrm{C}_{4} \\
\quad 140\end{array}$ & $\begin{array}{c}C_{3 / 10}+C_{3 /} \\
40\end{array}$ & $\mathbf{T}$ \\
\hline & $\mathrm{C}_{4 / 10}$ & $\mathrm{C}_{4 / 40}$ & $\mathrm{C}_{3 / 10}+\mathrm{C}_{3 / 4}$ & $\begin{array}{c}4 / 10+C_{4} \\
140\end{array}$ & $\mathrm{C}_{3 / 10}$ & $\mathrm{C}_{3 / 40}$ & $\mathrm{C}_{3 / 10}+\mathrm{M}^{\prime}$ & $\begin{array}{c}C_{3 / 10} \\
+M^{\prime} / 2\end{array}$ & $\mathrm{C}_{3 / 10}+\mathrm{N}$ & $\mathrm{C}_{3 / 40}$ & $\mathrm{C}_{3 / 10}$ & $\begin{array}{l}C_{4 / 40} \\
+M^{\prime}\end{array}$ \\
\hline & $\mathrm{C}_{3 / 10}+\mathrm{M}^{\prime}$ & $C_{3 / 10}+M^{\prime} / 2$ & $\mathrm{C}_{4 / 10}+\mathrm{M}^{\prime}$ & $\begin{array}{c}C_{4 / 10} \\
+M^{\prime} / 2\end{array}$ & $\mathrm{C}_{4 / 10}+\mathrm{M}^{\prime}$ & $C_{4 / 40}+M^{\prime}$ & $\begin{array}{c}C_{3 / 10}+C_{3 /} \\
40\end{array}$ & $\begin{array}{c}\mathrm{C}_{4 / 10}+\mathrm{C}_{4} \\
1 / 40\end{array}$ & $\begin{array}{c}C_{3 / 10} \\
+M^{\prime} / 2\end{array}$ & $\begin{array}{l}C_{4 / 10} \\
+M^{\prime} / 2\end{array}$ & $\begin{array}{c}C_{4 / 10}+C_{4 l} \\
40+M^{\prime}\end{array}$ & $\begin{array}{c}C_{4 / 10} \\
+M^{\prime} / 2\end{array}$ \\
\hline & $\begin{array}{c}\mathrm{C}_{3 / 10}+\mathrm{C}_{3 / 40} \\
+\mathrm{M}^{\prime}\end{array}$ & $\begin{array}{c}C_{3 / 10}+C_{3 / 40} \\
+M^{\prime} / 2\end{array}$ & $\begin{array}{c}\mathrm{C}_{4 / 10}+\mathrm{C}_{4 / 40} \\
+\mathrm{M}^{\prime}\end{array}$ & $\begin{array}{c}C_{4 / 10}+C_{4 /} \\
,+M^{\prime} / 2\end{array}$ & $\begin{array}{c}C_{1 / 10} \\
+M^{\prime} / 2\end{array}$ & $\begin{array}{l}C_{1 / 10} \\
+M^{\prime} / 2\end{array}$ & $\begin{array}{l}C_{4 / 10} \\
+M^{\prime} / 2\end{array}$ & $\begin{array}{l}C_{4 / 40} \\
+M^{\prime} / 2\end{array}$ & $\begin{array}{l}\mathrm{C}_{3 / 10}+\mathrm{C}_{3 /} \\
40+\mathrm{M}^{\prime} / 2\end{array}$ & $3_{1 / 10}+M$ & $\begin{array}{l}C_{4 / 10}+C_{4 /} \\
40+M^{\prime} / 2\end{array}$ & $\begin{array}{c}\mathrm{C}_{3 / 10^{+}} \\
\mathrm{C}_{3 / 40} \\
+\mathrm{M}^{\prime}\end{array}$ \\
\hline & $C_{3 / 40}+M^{\prime}$ & $C_{3 / 40}+M^{\prime} / 2$ & $C_{4 / 40}+M^{\prime}$ & $\begin{array}{r}C_{4 / 40} \\
+M^{\prime} / 2\end{array}$ & $\begin{array}{c}C_{1 / 10}+C_{1 /} \\
{ }_{40}+M / 2\end{array}$ & $\begin{array}{c}C_{1 / 10}+C_{1 /} \\
40+M^{\prime}\end{array}$ & $\mathrm{C}_{3 / 10}+\mathrm{M}^{\prime}$ & $\mathrm{C}_{3 / 40}+\mathrm{M}$ & $M^{\prime}$ & $\mathrm{C}_{4 / 40}$ & $\begin{array}{l}C_{9 / 10} \\
+M^{\prime} / 2\end{array}$ & $\mathrm{C}_{4 / 10}$ \\
\hline
\end{tabular}

: Irrigation canals;

\section{$\longrightarrow$ : spray nozzles.}

Watering was provided with watering channels having spray nozzles at their ends. Watering is ensured during several phases: emergence, tuberisation and maturity of the two crops.

Weeding and hoeing were made three weeks after the first watering and weed emergence.

This mounding limits the contamination of the tuber and favors tuberization. This operation was carried out when the stems reached $25 \mathrm{~cm}$ in height. It was repeated during the period of plant growth 
Note: Urea $46 \% \mathrm{~N}$ has been used after the vegetation was lifted.

All the various compost are in the dose $\mathbf{D}=30$ Tons/Hectare

$\mathbf{M}=10$ quintals/hectare NPK $15.15 .15+3$ quintals/hectare urea $46 \% \mathrm{~N}$

$\mathbf{M} / \mathbf{2}=$ Half the dose $\mathrm{M}$

$\mathbf{M}^{\prime}=5$ quintals/hectare NPK $15.15 .15+1.5$ quintals/hectare urea $46 \% \mathrm{~N}$

$\mathbf{M}^{\prime} / \mathbf{2}=$ Half the dose $\mathbf{M}^{\prime}$

\section{RESULTS AND DISCUSSION}

\section{A. Quality of composts}

Organic amendments are composts whose elements trace metallic must not exceed the limit values of international standards. They are rich in nutrients and contain no impurities.

\section{1) Chemical elements}

The chemical elements of the various composts are in agreement with other chemical characteristics of composts derived from fermentable (table IV).

TABLE IV. Chemical characteristics of the composts

\begin{tabular}{|c|c|c|c|c|c|c|c|c|c|}
\hline Compost & $\mathbf{C}_{\mathbf{1 / 1 0}}$ & $\mathbf{C}_{\mathbf{1 / 4 0}}$ & $\mathbf{C}_{\mathbf{2 / 1 0}}$ & $\mathbf{C}_{\mathbf{2} / \mathbf{4 0}}$ & $\mathbf{C}_{\mathbf{3} / \mathbf{1 0}}$ & $\mathbf{C}_{\mathbf{3} / \mathbf{4 0}}$ & $\mathbf{C}_{\mathbf{4} / \mathbf{1 0}}$ & $\mathbf{C}_{\mathbf{4 / 4 0}}$ & $\begin{array}{c}\mathbf{N F U} \\
\mathbf{4 4 ~ 0 5 1}\end{array}$ \\
\hline $\mathbf{p H} / \mathrm{DM}$ & 8 & 8 & 9 & 9 & 9 & 9 & 8 & 9 & - \\
\hline $\mathbf{\% ~ O M} / \mathbf{D M}$ & 38 & 37 & 39,5 & 37 & 38,8 & 36 & 34 & 32 & $\geq 20 \% \mathrm{MB}$ \\
\hline $\mathbf{\%} \mathbf{C} / \mathbf{D M}$ & 19 & 18,5 & 19,75 & 18,5 & 19,4 & 18 & 17 & 16 & $\geq 10$ \\
\hline $\mathbf{\%} \mathbf{N}-(\mathbf{N T K}) / \mathbf{D M}$ & 1,01 & 1.02 & 1,0 & 1,01 & 1.20 & 1,02 & 0,96 & 0,99 & $<3 \%$ \\
\hline $\mathbf{C / N}$ & 18,8 & 18 & 19,8 & 18,3 & 16,2 & 17,6 & 17,7 & 16,1 & 16,2 \\
\hline
\end{tabular}

The rate of the carbon is measured in relation to the volatile matter, which is determined by the loss at fire. The values of the $\mathrm{C} / \mathrm{N}$ ratios show that, the higher the $\mathrm{C} / \mathrm{N}$ ratio, the less the nitrogen is readily available. These results confirm that nitrogen is in the organic form, indicating that the various composts are of the organic amendments [8]. The values of the $\mathrm{pH}$ vary between 8 and 9. What indicating that the composts are mature. According to Avnimelech and al [1], mature composts are characterized by $\mathrm{pH}$ values ranging from 7 to 9 . The rates of the Organic matter are in compliance with various international standards.

\section{2) Fertilizer elements}

The mineral elements $(\mathrm{P}$ and $\mathrm{K}$ ) and trace elements $(\mathrm{Ca}, \mathrm{Mg}$ and $\mathrm{Na}$ ) act on the physical, biological and chemical stability of soils [3].

TABLE V. Fertilizer elements

\begin{tabular}{|c|c|c|c|c|c|}
\hline Compost & $\mathrm{Kg} \mathbf{P} / \mathrm{kg}$ & $\mathrm{Kg} \mathrm{K} / \mathrm{kg}$ & $\mathrm{Kg} \mathrm{Na} / \mathrm{kg}$ & $\mathrm{Kg} \mathrm{Mg} / \mathrm{kg}$ & $\mathrm{Kg} \mathbf{C a} / \mathrm{kg}$ \\
\hline $\mathrm{C}_{1 / 10}$ & 9,8 & 10,4 & 8,1 & 4,5 & 15,3 \\
\hline $\mathrm{C}_{1 / 40}$ & 9,7 & 9,5 & 7,5 & 4,3 & 14,5 \\
\hline $\mathrm{C}_{2 / 10}$ & 15,6 & 7,4 & 9,9 & 5,5 & 19,5 \\
\hline $\mathrm{C}_{2 / 40}$ & 13,6 & 7,1 & 9,2 & 4,9 & 17,9 \\
\hline $\mathrm{C}_{3 / 10}$ & 5,4 & 9,1 & 7,3 & 5,6 & 27,2 \\
\hline $\mathrm{C}_{3 / 40}$ & 4,4 & 8,3 & 7,1 & 5,2 & 25,2 \\
\hline $\mathrm{C}_{4 / 10}$ & 9,6 & 8,2 & 6,7 & 5,6 & 16,3 \\
\hline $\mathrm{C}_{4 / 40}$ & 7,7 & 7,5 & 6,4 & 5,3 & 13,6 \\
\hline
\end{tabular}

According to table $\mathrm{V}$, the analysis shows that the various composts are rich in: phosphorus, potassium, sodium, magnesium and calcium. These results are in agreement with those of Compaoré [6] in Ouagadougou. And with, those of Soumaré [12]. And, those of Charny [5]. And, those of Koledzi [10]. These elements can be provided by fermentable urban solid [5]. 


\section{3) Impurities}

The methods of analysis the inert components in the compost consists in destroying the non-synthetic organic matter by attack oxidative at bleach (13\%). This method is mentioned in norm NFU 44051 , applicable to organic amendments and soil organic composts. The results show the presence of oxidizing and non-oxidizing organic matter (plastic, paper-board, unclassified fuels, glass, textile, wood, coal and fine materials $(\leq 2 \mathrm{~mm})$ ). Composts contain impurities (Table VI), but the rates do not exceed the limits recommended by NFU 44051. These results confirm that it is important to mention that the different composts are the result of a tri-composting process. The composts obtained may be marketed and may be used in agriculture.

TABLE VI. Rate of impurities (/DM)

\begin{tabular}{|c|c|c|c|c|c|}
\hline Compost & $\mathbf{C}_{\mathbf{1}}$ & $\mathbf{C}_{\mathbf{2}}$ & $\mathbf{C}_{\mathbf{3}}$ & $\mathbf{C}_{\mathbf{4}}$ & NFU 44 051 \\
\hline Impurities & \multicolumn{5}{|c|}{$\% / \mathrm{DM}$} \\
\hline plastic & 0,1 & 0,2 & 0,4 & 0,7 & $<0,8 \%$ \\
\hline Paper-cardboard & 3.4 & 11,3 & 11,5 & 3,412 & - \\
\hline Metals & 0,1 & 0,1 & 0,2 & 0,3 & $<2 \%$ \\
\hline Glass & 0,1 & 0,2 & 0,4 & 0,7 & $<2 \%$ \\
\hline Unclassified fuels & 5,6 & 10 & 13,2 & 14,8 & - \\
\hline Textile & 0,1 & 0,2 & 1,6 & 2,9 & \\
\hline OMO & 35 & 30,9 & 29,7 & 24,5 & \\
\hline Fine Matter $<2 \mathrm{~mm}$ & 29,4 & 26,6 & 26,1 & 20,9 & \\
\hline
\end{tabular}

OMO: Organic Matter Oxidizing; DM: Dry Matter

\section{4) Elements Trace Metallic}

In this study, five (05) elements were analyzed: Cadmium, Copper, Lead, Nickel and Zinc. The rates of these elements do not exceed the limit values recommended by the various international standards (table VII).

TABLE VII. Rate of Elements Trace Metallic

\begin{tabular}{|c|c|c|c|c|c|c|c|c|c|c|c|c|}
\hline $\begin{array}{l}\mathbf{E M T} \\
(\mathbf{m g} / \mathbf{k g} \\
\mathbf{I D M}\end{array}$ & $\mathbf{C}_{\mathbf{1 / 1 0}}$ & $\mathbf{C}_{\mathbf{1 / 4 0}}$ & $\mathbf{C}_{\mathbf{2} / \mathbf{1 0}}$ & $\mathbf{C}_{\mathbf{2} / \mathbf{4 0}}$ & $\mathbf{C}_{\mathbf{3} \mathbf{1 0}}$ & $\mathbf{C}_{\mathbf{3} / \mathbf{4 0}}$ & $\mathbf{C}_{\mathbf{4} / \mathbf{1 0}}$ & $\mathbf{C}_{\mathbf{4} / \mathbf{4 0}}$ & NFU 44051 & $\begin{array}{c}\text { Allemagne } \\
\text { Biowaste } \\
\text { Ordinance I }\end{array}$ & $\begin{array}{l}\text { Australie } \\
\text { ARMCANZ* }\end{array}$ & $\begin{array}{l}\text { Canada } \\
\text { BNQ** }\end{array}$ \\
\hline $\mathbf{C d}$ & 0,2 & 0,2 & 0,6 & 0,9 & 0,6 & 0,3 & 0,4 & 0,5 & 3 & 1 & 3 & 3 \\
\hline $\mathbf{C u}$ & 72,6 & 73,7 & 83,7 & 84,8 & 94,3 & 93,7 & 95,5 & 92,0 & 300 & 70 & 200 & 100 \\
\hline $\mathbf{P b}$ & 41,1 & 42,5 & 55,7 & 55,9 & 73,5 & 83,7 & 92,6 & 93,9 & 180 & 100 & 200 & 150 \\
\hline $\mathbf{N i}$ & 12,2 & 12,0 & 16,5 & 14,3 & 22,8 & 21,9 & 36,6 & 35,7 & 60 & 35 & 60 & 62 \\
\hline $\mathbf{Z n}$ & 185,0 & 146,3 & 227,0 & 244,0 & 350,6 & 357,3 & 460,3 & 448,0 & 600 & 300 & 250 & 500 \\
\hline
\end{tabular}

\section{B. Compost maturity}

\section{1) Phytotoxicity}

The germination tests and the germination index tests are a means of evaluating the toxicity associated with the incorporation of compost in the soil.

The rate of germination index of cress and lettuce is significantly higher with the $50 \%$ compost water (CW) dose. Similarly, the highest corn and wheat germination rates were obtained with $50 \%$ of compost (table VIII). According to Compaoré [6], the germination varies with the dose of the compost brought and the type of crop. The results are in agreement with those found by Compaoré [7]. So the compost is ripe and can be used as organic amendments.

TABLE VIII. Rate of germination index and rate of germination

\begin{tabular}{|c|c|c|c|c|c|c|c|c|c|c|c|c|}
\hline \multirow{2}{*}{$\begin{array}{c}\text { Dose } \\
\text { Compost }\end{array}$} & \multicolumn{4}{|c|}{$100 \% \mathrm{E}$} & \multicolumn{4}{|c|}{$50 \% \mathrm{E}+50 \% \mathrm{CE}$} & \multicolumn{4}{|c|}{$100 \% \mathrm{CE}$} \\
\hline & $\mathrm{C}_{1}$ & $\mathrm{C}_{2}$ & $\mathrm{C}_{3}$ & $\mathrm{C}_{4}$ & $\mathrm{C}_{1}$ & $\mathrm{C}_{2}$ & $\mathrm{C}_{3}$ & $\mathrm{C}_{4}$ & $\mathrm{C}_{1}$ & $\mathrm{C}_{2}$ & $\mathrm{C}_{3}$ & $\mathrm{C}_{4}$ \\
\hline Cress & 100 & 100 & 100 & 100 & 78 & 85 & 74 & 72 & 69 & 67 & 56 & 52 \\
\hline Lettuce & 100 & 100 & 100 & 100 & 82 & 81 & 61 & 67 & 68 & 66 & 52 & 54 \\
\hline Dose & \multicolumn{4}{|c|}{$100 \%$ S (Sand) } & \multicolumn{4}{|c|}{$50 \% \mathrm{~S}+50 \% \mathrm{C}$} & \multicolumn{4}{|c|}{$100 \% \mathrm{C}$} \\
\hline Compost & $\mathrm{C}_{1}$ & $\mathrm{C}_{2}$ & $\mathrm{C}_{3}$ & $\mathrm{C}_{4}$ & $\mathrm{C}_{1}$ & $\mathrm{C}_{2}$ & $\mathrm{C}_{3}$ & $\mathrm{C}_{4}$ & $\mathrm{C}_{1}$ & $\mathrm{C}_{2}$ & $\mathrm{C}_{3}$ & $\mathrm{C}_{4}$ \\
\hline Wheat & 100 & 100 & 100 & 100 & 80 & 70 & 70 & 60 & 60 & 60 & 50 & 50 \\
\hline Corn & 100 & 100 & 100 & 100 & 70 & 60 & 60 & 50 & 60 & 60 & 50 & 50 \\
\hline
\end{tabular}




\section{Agronomic valorization}

It should be noted that the turnips (fig. 2) were seeded one year after seeding the potato (fig. 3).
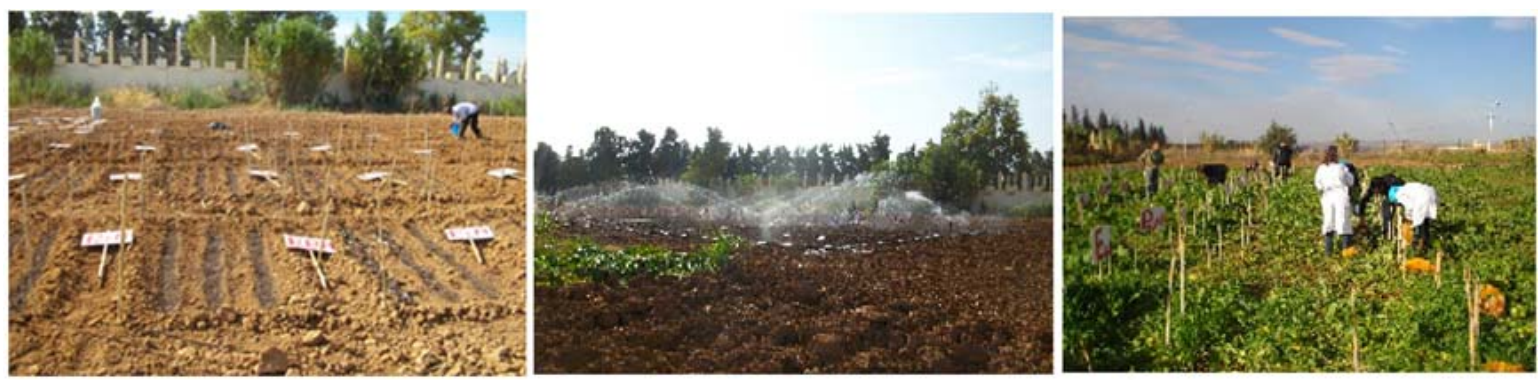

Fig. 2. Agronomic trials of the turnips
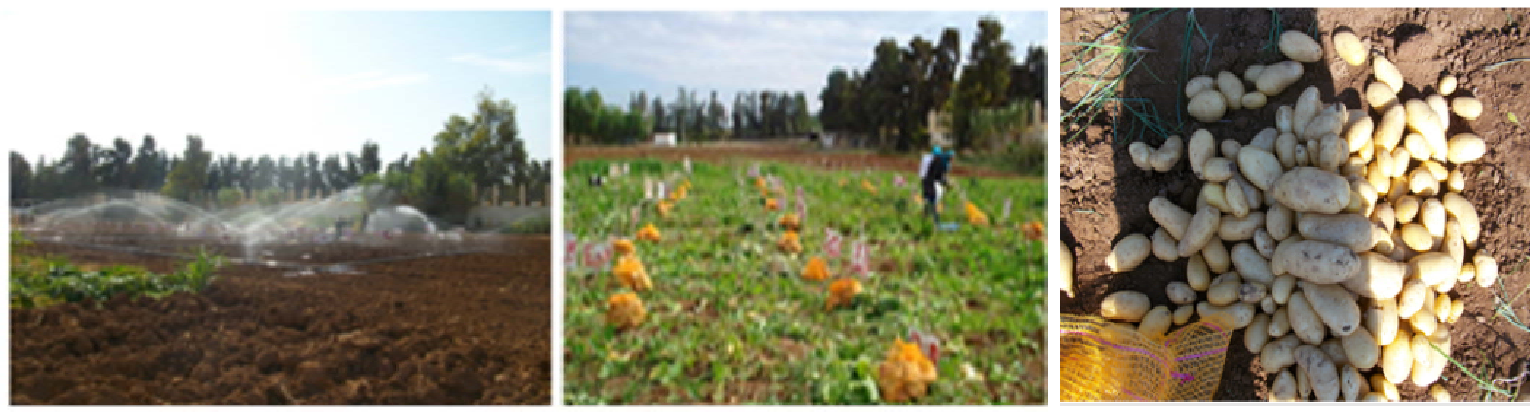

Fig. 3. Agronomic trials of the potatoes

\section{1) Fine compost}

\section{Yield of potatoes}

A dose of 30 tons/hectare of $\mathrm{C}_{1 / 10}$ or $\mathrm{C}_{2 / 10}$ compost added to a mineral fertilizer $\mathrm{M}$ dose yielded better potato yields ( 24 tons /hectare and 25 tons/hectare) compared to yields of control (17 tons and those of the M/2 doses (19 tons/hectare).On the other hand, a dose of $\mathrm{C}_{1 / 10}$ added to half a dose of mineral fertilizers gave yields of 26 tons/hectare at 30 tons/hectare. The compost mixed with half-doses of mineral fertilizers yield significant yields. These results show that nutrient deficiencies can be brought by the compost amendments (Fig. 4). So the farmers can use half a dose of mineral fertilizers instead of one dose for better soil fertility and a high rate of productivity in healthy cultivation for the human and for the environment.

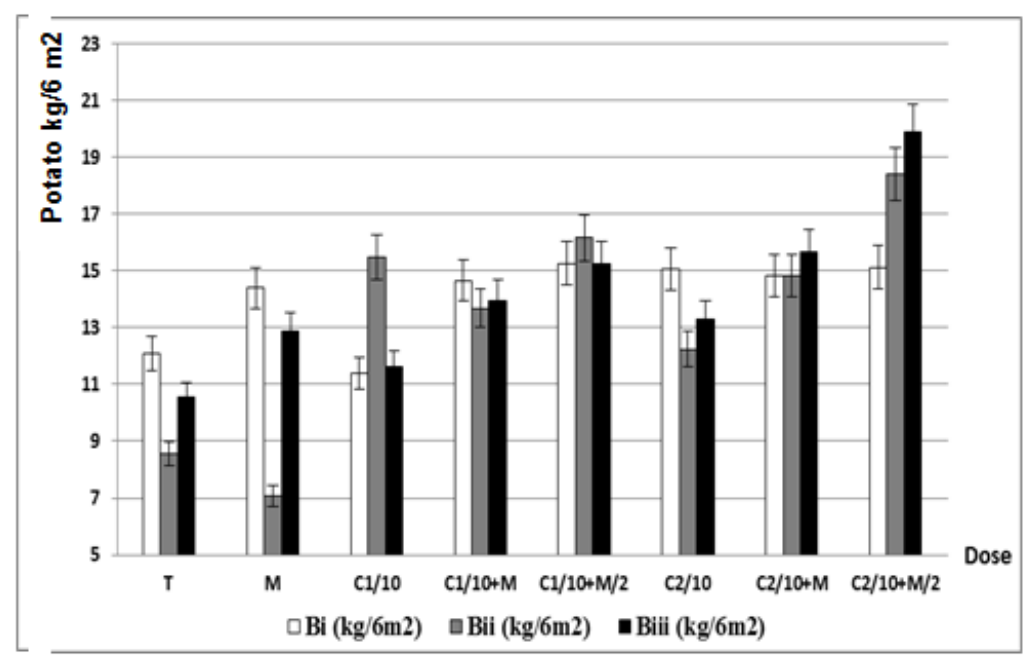

Fig. 4. Yield of potatoes

\section{Yield of turnips}

According to figure 3, the yields of the turnips brought by the $\mathrm{C}_{3 / 10}$ and $\mathrm{C}_{4 / 10}$ compost, are higher than those of the witness (T) and those of the dose $\mathrm{M}^{\prime}$ (fig. 5).

The yield of the dose $\left(\mathrm{M}^{\prime}+\mathrm{C}_{3 / 10}\right)$ is $7.93 \mathrm{~kg} / 2 \mathrm{~m}^{2}$ and this of the dose $\left(\mathrm{C}_{4 / 10}+\mathrm{M}^{\prime}\right)$, are important compared to this of witness and this of the dose $\mathrm{M}^{\prime}$. These results are due to the delayed effects of the amendments compost $\mathrm{C}_{1 / 10}$ 
and $\mathrm{C}_{2 / 10}$ which were seeded a year before with the potatoes. The organics amendments act on soil structure in contrast to mineral fertilizers.

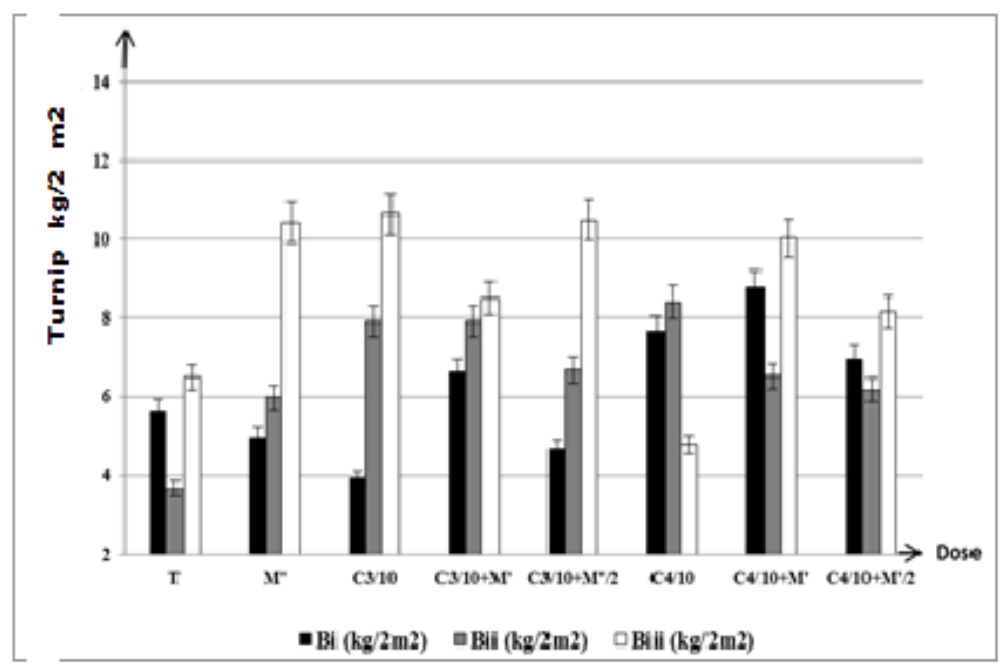

Fig. 5. Yield of turnips

\section{2) Coarse compost}

\section{Yield of potatoes}

The doses $\left(\mathrm{C}_{1 / 40}+\mathrm{M} / 2\right)$ and $\left.\left(\mathrm{C}_{2 / 40}+\mathrm{M} / 2\right)\right)$ give 31 tons/hectare and 32 tons/hectare (fig. 6$)$ of potato. These yields are superior to those obtained with compost associated with a dose $\mathrm{M}$ (24 tons/hectare and 31 tons/hectare). Several hypotheses can be considered: - The depressive effect is not related to the characteristics of the compost, but to the applied doses [2]; - the potato is favorably more sensitive to half a dose of mineral fertilizers added to a dose of compost.

These results confirm those found with fine compost. So, it is enough to farmers to use half a dose of mineral fertilizers with a dose of organic amendments (compost), to guarantee the needs and the unavailability of mineral fertilizers at the appropriate times. For this purpose, local production of the compost is essential in developing countries.

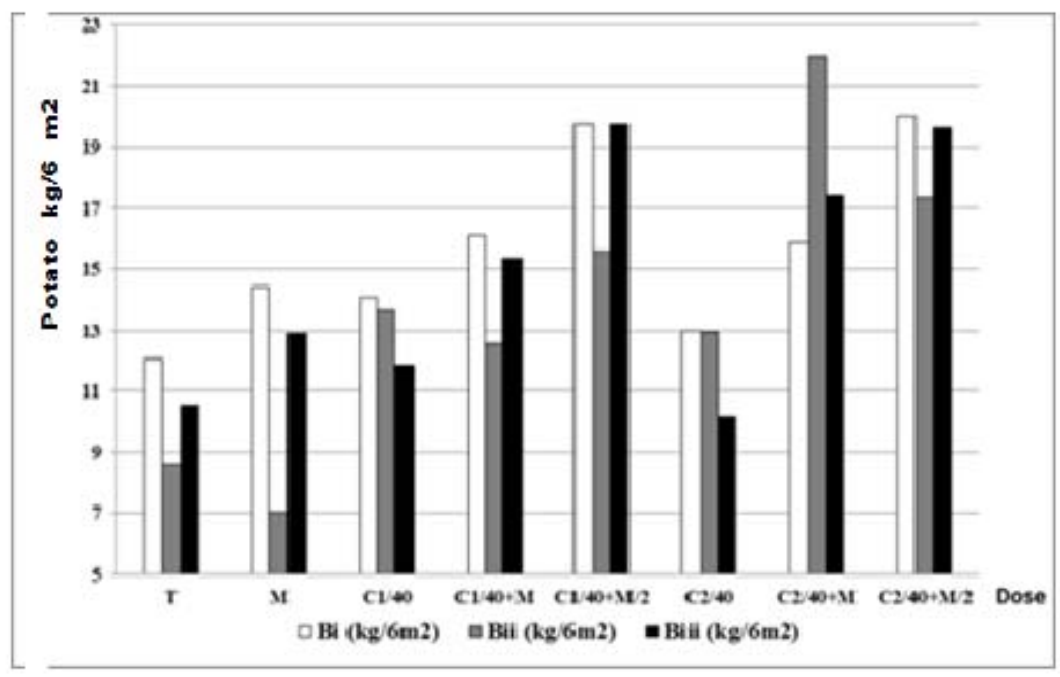

Fig. 6. Yield of potatoes

\section{Yield of turnips}

The doses $\left(\mathrm{C}_{3 / 40}+\mathrm{M}^{\prime}\right)$ and $\left(\mathrm{C}_{4 / 40}+\mathrm{M}^{\prime}\right)$, yielded significantly higher yields than those given by the witness miniparcel and the mini-parcel of mineral fertilizer dose ( $\left.\mathrm{M}^{\prime}\right)$ (fig. 7). The highest yield is obtained with the $\left(\mathrm{C}_{4 / 40}+\right.$ $\mathrm{M}^{\prime}$ ) dose (44 tons/hectare). This result is related to the phosphorus content of Compost 4 compared to compost 3. The inputs of organic amendments rich in mineral elements and in trace elements seem to correct the deficiency in soil nutrient used in these agronomic trials. 


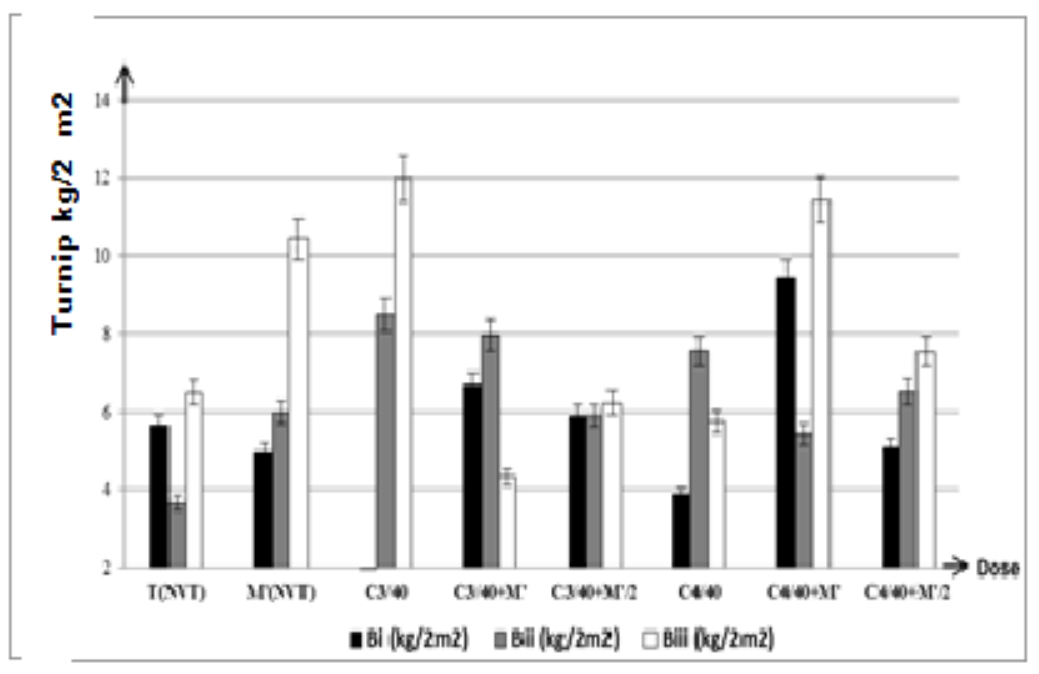

Fig. 7. Yield of turnips

\section{3) Comparison of potatoes yields}

A dose of 30 tons/hectare of organic amendments contains $300 \mathrm{~kg} \mathrm{~N} /$ hectare, $300 \mathrm{~kg} \mathrm{P}_{2} \mathrm{O}_{5} /$ hectare and $240 \mathrm{~kg}$ $\mathrm{K}_{2} \mathrm{O} /$ hectare. And a dose $\mathrm{M}$ of mineral fertilizers contains ten (10) quintals/hectare of NPK 15.15 .15 and three (03) quintals/hectare of urea $46 \%$ of $\mathrm{N}$. The mixing of these various fertilizers is necessary for the improvement of the texture of the arable soils. According to table IX, the results show that the yields of potato with the fine compost are more significant than those obtained with the coarse compost. Thus, fine compost has an advantage for vegetable crops.

TABLE IX. Potatoes yields obtained with fine compost and the coarse compost

\begin{tabular}{|c|c|c|c|c|c|c|c|c|}
\hline Treatment & $\mathbf{T}$ & $\mathbf{M}$ & $\mathbf{C}_{1 / 10}$ & $\mathbf{C}_{1 / 10}+\mathbf{M}$ & $\mathbf{C}_{1 / 10}+\mathbf{M} / \mathbf{2}$ & $\mathbf{C}_{2 / 10}$ & $\mathbf{C}_{2 / 10}+\mathbf{M}$ & $\mathbf{C}_{2 / 10}+\mathbf{M} / \mathbf{2}$ \\
\hline Tons/Hectare & 17 & 19 & 21 & 24 & 26 & 23 & 25 & 30 \\
\hline Treatment & $\mathbf{T}$ & $\mathbf{M}$ & $\mathbf{C}_{\mathbf{1 / 4 0}}$ & $\mathbf{C}_{1 / 40}+\mathbf{M}$ & $\mathbf{C}_{\mathbf{1 / 4 0}}+\mathbf{M} / \mathbf{2}$ & $\mathbf{C}_{2 / 40}$ & $\mathbf{C}_{2 / 40}+\mathbf{M}$ & $\mathbf{C}_{2 / 40}+\mathbf{M} / \mathbf{2}$ \\
\hline Tons/Hectare & 17 & 19 & 22 & 24 & 31 & 20 & 31 & 32 \\
\hline
\end{tabular}

According to the Directorate of Agricultural Services (DAS) of Chlef, the potatoes production (table X) varies between 28 tons/hectare and 39 tons/hectare. In Chlef the farmers use two doses of mineral fertilizer ( $2 \mathrm{M})$. And sometimes, two and a half doses $(2,5 \mathrm{M})$ to obtain these yields. These doses provide an excess of nitrogen that turns into nitrates. Nitrates are easily soluble in water.

So those that are not assimilated by plants are carried away by the runoff of the waters and pollute the ground and the ground water, while the compost allows for the supply of organic nitrogen which decomposes progressively.

Table X. Potatoes production at Chlef (DAS, 2016)

\begin{tabular}{|c|c|c|c|c|c|c|}
\hline Year & \multicolumn{2}{|c|}{ Season } & \multicolumn{2}{c|}{ Off-season } & \multicolumn{2}{c|}{ Total } \\
\hline & $\begin{array}{c}\text { Area } \\
\text { (hectare) }\end{array}$ & $\begin{array}{c}\text { Production } \\
\text { (tons/hectare) }\end{array}$ & $\begin{array}{c}\text { Area } \\
\text { (hectare) }\end{array}$ & $\begin{array}{c}\text { Production } \\
\text { (tons/hectare) }\end{array}$ & $\begin{array}{c}\text { Area } \\
\text { (hectare) }\end{array}$ & $\begin{array}{c}\text { Production } \\
\text { (tons/hectare) }\end{array}$ \\
\hline $\mathbf{2 0 1 4}$ & 2614 & $\mathbf{4 2}$ & $\mathbf{1 9 8 7}$ & $\mathbf{3 5}$ & $\mathbf{4 6 0 1}$ & $\mathbf{3 9}$ \\
\hline $\mathbf{2 0 1 5}$ & 2188 & 32 & 2223 & 25 & 4411 & 28 \\
\hline
\end{tabular}

3.1) Effect of the fine compost added to fertilizers minerals on the caliber of the potatoes and the caliber of the turnips

To better understand the effect of organics amendments added to fertilizers minerals on the yield of potatoes and turnips, the knowledge of the caliber of these two crops becomes necessary.

\section{Caliber of the potatoes}

In the case of fine compost added to fertilizers minerals, the percentage of potatoes, who's the caliber greater than $55 \mathrm{~mm}(\geq 55 \mathrm{~mm}$ ) is $53,8 \%$. For cons, the rate is $9,5 \%$ in the witness mini-parcel (without compost and without mineral fertilizers). These results show that fine compost acts as organic amendments and as organic fertilizers since they improve crop productivity and soil fertility (fig. 8). 

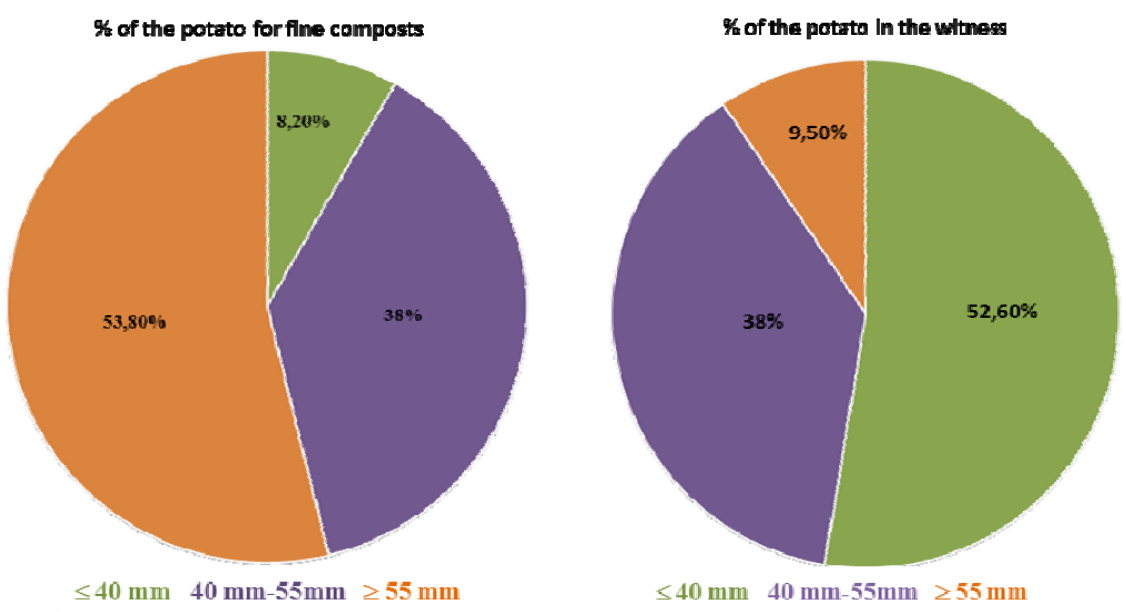

Fig. 8 Effect of fine compost added to fertilizers minerals on the potatoes caliber

\section{Caliber of turnips}

In the case of the application of the fine various compost added to the mineral fertilizers in the mini plots, the percentage of turnips with a caliber greater than $55 \mathrm{~mm}(\geq 55 \mathrm{~mm})$ is $58,5 \%$. The rate of this culture is $20,5 \%$ in the witness (fig. 9). These results are consistent with those found with potato. According to Soltner [11], good plant growth is not only related to the main fertilizing elements (nitrogen, phosphorus and potassium), but to the availability of trace elements $(\mathrm{Mg}, \mathrm{Zn}, \mathrm{Cu}, \mathrm{Na}$ and $\mathrm{Ca})$. This result is due to the richness of the soil of the fertilizers elements since the turnips were sown a year after the potatoes.
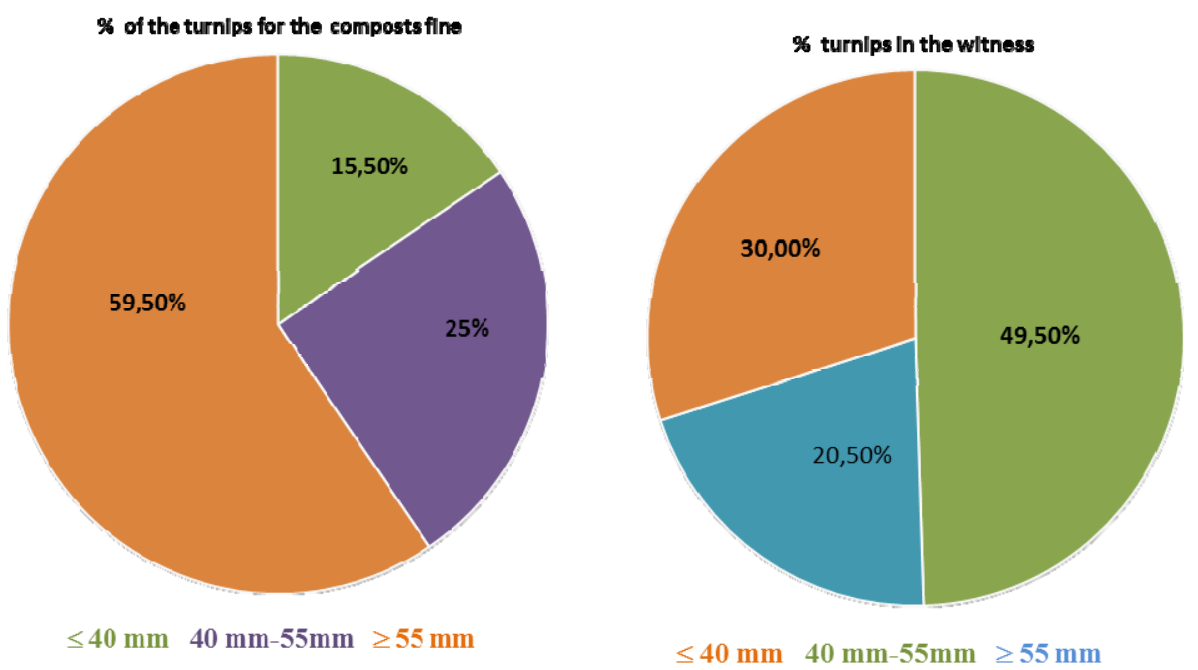

Fig. 9. Effect of fine compost added to fertilizers minerals on the turnips caliber

\section{2) Effect of coarse compost added to fertilizers minerals on the caliber of the potato and turnips Caliber of the potatoes}

The most significant potato percentages are those with caliber greater than $55 \mathrm{~mm}(\geq 55 \mathrm{~mm})$ and those with the caliber is $40 \mathrm{~mm}$ to $50 \mathrm{~mm}$. These rates are significantly higher than those obtained with the witness (fig. 10). These findings confirm that fine or coarse compost added to fertilizers minerals ameliorate the chemical, physical and biological characteristics of the soil and subsequently act as organic fertilizers. 

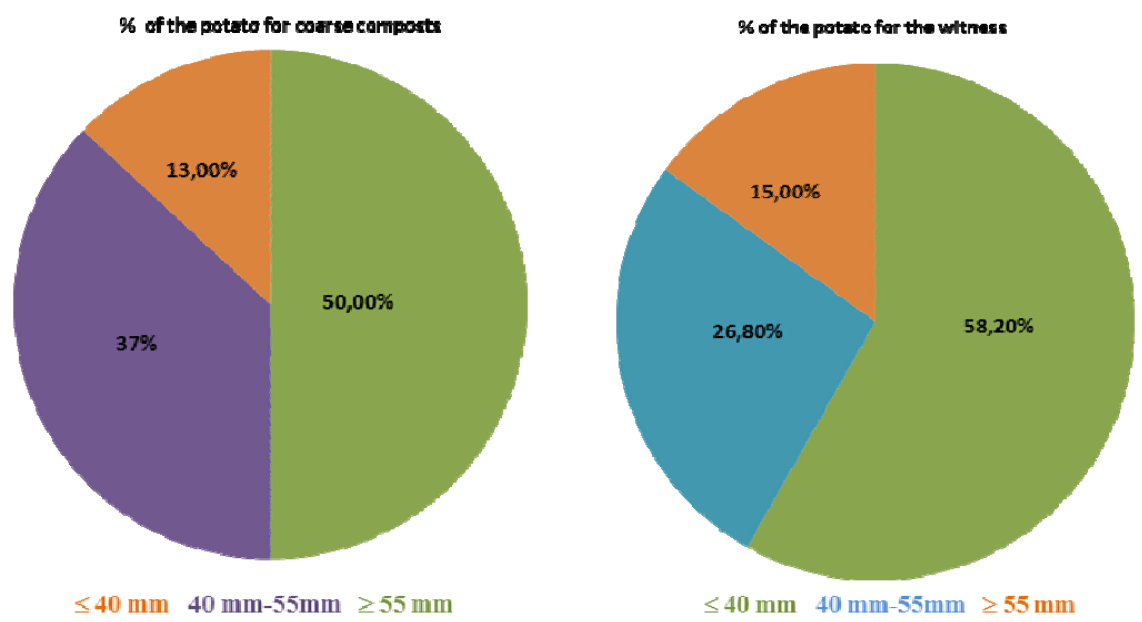

Fig. 10. Effect of coarse compost added to fertilizers minerals on the potatoes caliber

\section{Caliber of turnips}

In the case of coarse compost added to mineral fertilizers, the turnover rate greater than $55 \mathrm{~mm}(\geq 55 \mathrm{~mm})$ is significantly higher than that obtained by the control (Figure 11).These results are consistent with those found with the fine compost. According to Bouzaine [4], a soil treated with organics amendments, becomes rich in organic matter and microbial biomass over time.
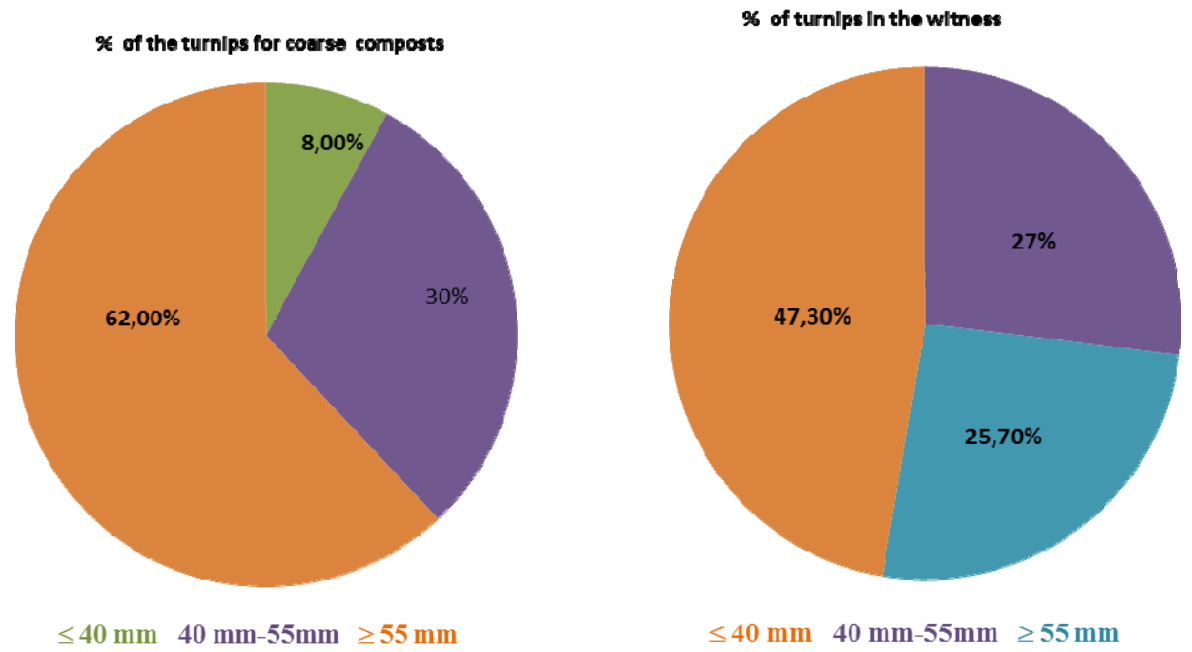

Fig. 11. Effect of coarse compost added to fertilizers minerals on the turnips caliber

\section{CONCLUSION}

The agronomic trials showed that the different compost of dimensions $10 \mathrm{~mm}$ and $40 \mathrm{~mm}$ improve the fertility of the soil, they act like organic amendments and as organics fertilizers.

A dose or half a dose of mineral fertilizer added to a compost dose does not affect the yields of both crops.

In addition, the results show that the highest yields of both crops above $55 \mathrm{~mm}(\geq 55 \mathrm{~mm})$ were obtained in the case where the compost is added to the mineral fertilizer. These findings show that compost is a complement to mineral fertilizer.

The results of this experiment are information tools, which show that the compost produced in Chlef, largely cover the needs of the fertilizers minerals. The composting has an advantage for Chlef and the departments neighboring because the organic matter of the compost can compensate of the deficiencies of the organic matter of agricultural soils.

This research / action have shown that composting is a suitable solution and confirms the importance and importance of the integration of this treatment in the waste management sector in the developing countries. However, conditions are necessary such as:

- Periodic characterization and composition of the compostable categories (Greens wastes and urban solid wastes); 
- Follow-up of the composting process;

- Quality and maturity analysis of the compost;

- Agronomics trials;

- Monitoring of the soil structure and the profitability of the cultures.

\section{REFERENCES}

[1] Avnimelech Y., Bruner M., Ezrony I., Sela R., and Kochba M. "Stability indexes for municipal solid waste compost. Compost Science \& Utilization, 4, 2:13-20. 1996

[2] M. Abad Berjon, M. D. Climent Morato , P. Aragón Revuelta \& A. Camarero Simon . "The influence of solid urban waste compost and nitrogen-mineral fertilizer on growth and productivity in potatoes." . Communications in Soil Science and Plant Analysis. Volume 28, 1997 - Issue 17-18. 2008

[3] Bertoldi M., De,Vallini G. andPera A. "The biology of composting: a review". Waste Management \& Research 1: 157-176. 1983

[4] Bouzaiane O., Cherif H., Saidi N., Jedid N et Hassen A. «Effects of municipal solid waste application on the microbial biomass of cultivated and non-cultivated soil in a semi-arid zone waste Management. Research 25, 334-342. 2007

[5] Charny. "Composting urban waste in developing countries. Elaboration of a methodological approach for a sustainable production of compost". Doctoral thesis $n^{\circ}$ 562005, University of Limoges. 2005

[6] Compaoré E \& Nanéma L.S. "Composting and quality of the solid urban waste compost in the city of Bobo-Dioulasso, Burkina Faso". TROPICULTURA, 2010, 28, 4, 232-237. 2010

[7] Compaoré, W.R., Nikièma,P.A., Bassolé, H.I.N.,A. Savadogo, A., Mouecoucou,J., Hounhouigan D.J.and Traoré , S.A. Chemical Composition and Antioxidative Properties of Seeds of Moringa oleifera and Pulps of Parkia biglobosa and Adansonia digitata Commonly used in Food Fortification in Burkina Faso. Current Research Journal of Biological Sciences 3(1): 64-72, 2011.

[8] Equiterre. "Amendment and fertilization - Chapter 12, "Organic amendments, fertilizer and compost", manuscript of the Comprehensive Management Guide for the organic and diversified vegetable farm, drafted by Anne Weill and Jean Duval. 2009

[9] Giroux M. and Audesse P. "Comparison of two methods for determining organic carbon, total nitrogen and $\mathrm{C} / \mathrm{N}$ ratio of various organic amendments and manure". Institute to Research and Development in Agro-Environment. (IRDA). Agrosol P 107-110. 2004

[10] Koledzi. "Valorisation of urban waste: Implementation of decentralized composting in the Lomé neighborhoods; Methods and perspectives $\gg$ Doctoral thesis $n^{\circ} 04-2011$, University of Limoges. 2011

[11] Soltner. The basis of plant production Volume $1 "$. The soil and its improvement 14 th edition: collection of sciences and agricultural techniques, 472 p. 2003

[12] Soumaré M., Tack F and Verlo, M. "Characterization of Malian and Belgian solid waste composts with respect to fertility and suitability for land application". Waste Management. 23, 517-522. 2003

[13] Zucconi F., Pera A., Forte M. and De Bertoldi M. "Evaluating toxicity of immature compost". Biocycle 22: 54-57. 1981 